\title{
The Correlation Between Episiotomy, Perineal Laceration And Type Of Labor Toward The Incidence Of Pospartum Urinary Retensio At dr. H. Soemarno Sosroatmodjo Hospital Of Kuala Kapuas In 2015-2016.
}

\author{
Filistea Winda Emilia ${ }^{1 *}$ \\ ${ }^{1}$ Departement of Science Midwifery AKBID Sari Mulia Banjarmasin Indonesia \\ *filistea_winda_emilia@akbidsarimulia.ac.id
}

\author{
Fitri Yuliana ${ }^{2}$ \\ ${ }^{2}$ Departement of Science Midwifery STIKES Sari Mulia Banjarmasin Indonesia \\ fitri_yuliana@stikessarimulia.ac.id \\ Rini Noviantina ${ }^{2}$ \\ ${ }^{2}$ Departement of Science Midwifery STIKES Sari Mulia Banjarmasin Indonesia \\ rini_noviantina@gmail.com
}

\begin{abstract}
Objective: To analyze the correlation between episiotomy, perineal laceration and type of labor toward the incident of postpartum urinary retention in Dr. H. Soemarno Sosroatmodjo Hospital Kuala Kapuas in 2015-2016

Method: The research used case control study and was conducted on March 13, 2017 - March 18, 2017 in Dr. H. Soemarno Sosroatmodjo Hospital of Kuala Kapuas. The study was conducted on 130 postpartum mothers divided into 65 postpartum women who had urinary retention as cases with total sampling technique and 65 postpartum mothers who could not retention urine as control by purposive sampling technique. Then, the collected data were analyzed using Chi-Square test.

Results: The results of research shows an correlation of episiotomy with the incidence of urinary retention $p=0.013$, perineal laceration with the incidence of urinary retention $p=0.007$ and the type of labor with the incidence of urinary retention $p=0.024$. Variables most at risk of postpartum urinary retention events is perineal laceration with $\mathrm{OR}=3,766$.

Conclusion: There was an on going correlation of episiotomy, perineal rupture and the type of labor toward the incidence of postpartum urinary retention.
\end{abstract}

Keywords: Episiotomy, Type of Labor, Urinary Retention, Perineal Laceration

\section{INTRODUCTION}

Assessing the health status of the community especially the health of mother and child can be seen from a sustainable program of Sustainable Development Goals (SDGs) replacing the Millennium

Development Goals (MDGs ) with a target in 2030 to reduce MMR to $70 / 100,000$ live births ${ }^{6}$.
According to a World Health Organization (WHO ) report published in 2014 , Maternal Mortality Rate (AKI ) in the world reached 289,000 people . Based on the Indonesia Demographic and Health Survey (IDHS ) in 2012, Maternal Mortality Rate (MMR ) in Indonesia is 359 per 100,000 live births , but this number has decreased to 305 deaths per 100,000 live births based on the 
2015 Intercensal Population Survey $(\text { SUPAS })^{6}$.

Maternal Mortality Rate (MMR ) in the province of Central Kalimantan in 2014 amounted to $101 / 100,000$ live births increased compared to the year 2013 of 75 / 100,000 live births (Central Kalimantan Provincial Health Office , 2014 ) . The number of MMR reported (1)in 2014 in Kapuas District was 147 / 100,000 (2)live births, this number decreased when compared to the year of 2013 of $150 / 100,000$ live births ${ }^{5}$.

The cause of death Mother is divided into two namely the direct cause and indirect cause. The immediate cause of maternal death is bleeding $40-60 \%$, pre eclampsion $20-30 \%$ and infection $20-30 \%$. One of the causes of bleeding and infection is postapital urinary retention

Urinary retention causes bladder distension which then pushes the uterus upward and laterally. This condition usually prevents the uterus contracting well which eventually causes bleeding. Postpartum hemorrhage is one of them caused by inadequate uterine contractions. Uterine contractions weaken due to full post partum bladder or by urinary retention

The incidence of urinary retention is a problem that needs to be considered in the postpartum period. This postpartum urinary retensio hazard also results in uremia and sepsis, even resulting in spontaneous rupture of vesica urinaria. Trauma can occur in the urethra and bladder during childbirth arising from impulse during delivery as the baby passes through the birth canal. The bladder wall may develop hyperemia and edema. Pain around the perineum due to vaginal laceration leads to urinary tract and episiotomy resulting in a burning sensation that decreases or alters urinary reflexes ${ }^{13,17}$.

The incidence of urinary retention in the post partum period, according to Saultz (1991) ranged from $1.7 \%$ to $17.9 \%$. A study conducted by Yip (1997) found a postpartum retensio incident incidence of $4.9 \%$ with 150 cc urine residual volume as a normal volume after spontaneous urination7. Postpartum retention most commonly occurs after a spontaneous vaginal birth, bladder dysfunction occurs $9-14 \%$ after birth using forcep, this number increases to $38 \%{ }^{15}$.

The study by Pribakti et al titled "Review of postpartum urinary retention case at RSUD Ulin Banjarmasin 2002-2003" showed the incidence of post partum urinary retention of $0.38 \%$ of 1,891 spontaneous deliveries and 222 deliveries with vacuum extraction. The highest age was 26-30 year age group $(36,3 \%)$ and partial majority was primipara $(54,5 \%)$. Based on the act of delivery was spontaneous pervaginam 8 cases $(81,8 \%)$, vacuum extraction 2 case $(18,2 \%)$ and cesarean sectio 1 case $(1 \%)^{11}$.

The results of preliminary studies that have been done in hospitals dr. H. Soemarno Sosroatmodjo Kuala Kapuas, it was found that the incidence of urinary retention per year 
is up and down. In 2014 there is $4.2 \%$ of cases of 757 postpartum women, 2015 increased by $4.7 \%$ of cases of 877 postpartum women, but in 2016 a slight decrease of $2.74 \%$ of cases of 837 postpartum women due to in early $2016 \mathrm{dr}$.Obgyn at the Soemarno Sostroatmodjo General Hospital was not in place so most cases were referred to hospitals that had dr.Obgyn.

Based on the above background, then can dilakukukan research on the relationship episiotomi, perineum rupture and type of delivery with Retensio Urine Post Partum Occurrence in RSUD dr. H. Soemarno Sosroatmodjo Kuala Kapuas Year 2015-2016.

\section{METHODS}

This research uses analytical survey method with case control design. The sample is divided into two case samples and control samples. Cases are all postpartum women experiencing urinary retention in the Nifas room RSUD dr. H. Soemarno Sosroatmodjo Kuala Kapuas period 2015-2016 as many as 65 postpartum mothers with total sampling technique, while the control is all postpartum who do not experience urinary retention in space of Niras RSUD dr. H. Soemarno Sosroatmodjo Kuala Kapuas used a ratio of 1: 1 matching age and parity with purposive sampling technique. The inclusion criteria are the history of labor now with normal vaginal, vacuum extraction and caesarea section. Exclusion criterion in this research that is history of labor now with forcep extraction because not done in RSUD dr. H. Soemarno Sosroatmodjo Kuala Kapuas. Data collection by using research form with data processing using chi square test.

\section{RESULT}

Characteristics of Respondents

Table 1 Frequency Distribution Characteristics of Respondents in RSUD Dr. H. Soemarno Sosroatmodjo Kuala Kapuas Year 2015-2016

\begin{tabular}{clcc}
\hline No & Characteristics & Frekuensi & Persentation \\
\hline 1 & age & & \\
& $<20$ tahun & 6 & 4,6 \\
& $20-35$ tahun & 106 & 81,5 \\
& $>35$ tahun & 18 & 13,9 \\
2 & Paritas & 52 & 40 \\
& Primipara & 74 & 56,9 \\
& Multipara & 4 & 3,1 \\
\hline
\end{tabular}

Table 1 shows that most of the puerperal mothers in the hospital room drew dr. $\mathrm{H}$. Soemarno Sosroatmodjo Kuala Kapuas between the ages of 20-35 years as many as 106 postpartum $(81.5 \%)$ and most of them are 74 postpartum Mothers (56.9\%).

\section{Univariate Analysis}

Table 2 Distribution of Variable Frequency of Univariate Analysis in RSUD dr H. Soemarno Sosroatmodjo Kuala Kapuas Year 2015-2016

\begin{tabular}{clcc}
\hline No & \multicolumn{1}{c}{ Variabel } & Frekuensi & Persentasi \\
\hline 1 & Retension of Urin & & \\
& Yes & 65 & 50 \\
& No & 65 & 50 \\
2 & Episiotomi & & \\
& Yes & 76 & 58,5 \\
& No & 54 & 41,5 \\
3 & Perineal Rupture & 106 & 81,5 \\
& Yes & 24 & 18,5 \\
& No & & \\
Type of Labor & 84 & 64,6 \\
& Normal & 22 & 16,9 \\
& Vacuum Extraction & 24 & 18,5 \\
$\quad$ Seksio Casearea &
\end{tabular}

Table 2 shows that postpartum in childbirth room dr. H. Soemarno Sosroatmodjo Kuala Kapuas with urinary retention of 65 postpartum (50\%), 76 postpartum (58.5\%) episiotomy, perineum rupture 106 puerperal 
mother $(81,5 \%)$ and type of labor normal delivery of 84 postpartum (64.6\%).

\section{Bivariate Analysis}

\section{Episiotomy Relationship with Retensio}

\section{Post Urine Particle Occurrence}

Table 3 Relationship of Episiotomy with Retensio Postal Urine Post Occurrence in RSUD Dr. H. Soemarno Sosroatmodjo Kuala Kapuas Year 2015-2016

\begin{tabular}{ccccccc}
\hline \multirow{2}{*}{ Episiotomi } & \multicolumn{2}{c}{ Cases } & \multicolumn{2}{c}{ Control } & \multicolumn{2}{c}{ Jumlah } \\
\cline { 2 - 7 } & $\mathrm{n}$ & $\%$ & $\mathrm{n}$ & $\%$ & $\mathrm{n}$ & $\%$ \\
\hline Yes & 45 & 69,2 & 31 & 47,7 & 76 & 58,5 \\
\hline No & 20 & 30,8 & 34 & 52,3 & 54 & 41,5 \\
\hline Jumlah & 65 & 100 & 65 & 100 & 130 & 100 \\
\hline
\end{tabular}

Chi Square $p=0,013 \alpha=0,05 p<\alpha$

Odds Ratio OR = 2,468 $(1,205-5,056)$

Respondents were subjected to episiotomy in cases with post partum urinary retention of 45 people (69.2\%), whereas in the control group the most did not do episiotomy amounted to 34 people (52.3\%). Chi Square test results show $\mathrm{p}=0.013$ means there is a significant relationship between episiotomy with post partum urine retention incident in RSUD dr. H. Soemarno Sosroatmodjo Kuala Kapuas 2015-2016 with the value of OR (Odds Ratio) 2,47 means that mother done episiotomy at risk 2,47 times experiencing post partum urineretention.

\section{Relationship of the Perineum Rupture with}

\section{Retensio Postpartum Urine Occurrence}

Table 4 Relationship of Perineum Rupture with Retensio Postal Urine Post Occurrence in RSUD Dr. H. Soemarno Sosroatmodjo Kuala Kapuas Year 20152016

\begin{tabular}{ccccccc}
\hline Ruptur & \multicolumn{2}{c}{ Kasus } & \multicolumn{2}{c}{ Kontrol } & \multicolumn{2}{c}{ Jumlah } \\
\cline { 2 - 7 } Perineum & $\mathrm{n}$ & $\%$ & $\mathrm{n}$ & $\%$ & $\mathrm{~N}$ & $\%$ \\
\hline Ya & 59 & 90,8 & 47 & 72,3 & 106 & 81,5 \\
\hline Tidak & 6 & 9,2 & 18 & 27,7 & 24 & 18,5 \\
\hline Jumlah & 65 & 100 & 65 & 100 & 130 & 100 \\
\hline \multicolumn{3}{c}{ Chi Square $\boldsymbol{p}=\mathbf{0 , 0 0 7}$} & $\boldsymbol{\alpha}=\mathbf{0 , 0 5}$ & $\boldsymbol{p}<\boldsymbol{\alpha}$ \\
Odds Ratio OR $=\mathbf{3 , 7 6 6}$ & $(\mathbf{1 , 3 8 5}-\mathbf{1 0 , 2 3 9 )}$
\end{tabular}

Respondents who experienced rupture perineum in the case were 59 people $(90.8 \%)$, while the control group that experienced rupture perineum amounted to 47 people (72.3\%). Chi Square test results show $\mathrm{p}=$ 0.007 means there is a significant relationship between perineum rupture with post partum urinary retention incident in RSUD dr. $\mathrm{H}$. Soemarno Sosroatmodjo Kuala Kapuas 20152016 with OR (Odds Ratio) 3,77 means that mothers who have perineal rupture are at risk 3,77 times have post partum urine retention.

\section{Relation Type of Labor with Retensio Post} Urum Part Event

Table 5.Relationship Type of Labor with Retensio Postpartum Post Urinary Event in RSUD dr $\mathrm{H}$. Soemarno Sosroatmodjo Kuala Kapuas Year 20152016

\begin{tabular}{ccccccc}
\hline \multirow{2}{*}{ Jenis Persalinan } & \multicolumn{2}{c}{ Kasus } & \multicolumn{2}{c}{ Kontrol } & \multicolumn{2}{c}{ Jumlah } \\
\cline { 2 - 7 } & $\mathrm{n}$ & $\%$ & $\mathrm{n}$ & $\%$ & $\mathrm{n}$ & $\%$ \\
\hline Normal & 46 & 70,8 & 38 & 58,5 & 84 & 64,6 \\
\hline Vakum Ektraksi & 13 & 20 & 9 & 13,8 & 22 & 16,9 \\
\hline Seksio Sesarea & 6 & 9,2 & 18 & 27,7 & 24 & 18,5 \\
\hline Total & 65 & 100 & 65 & 100 & 130 & 100 \\
\hline \multicolumn{3}{c}{ Chi Square p $=\mathbf{0 , 0 2 4}$} & $\boldsymbol{\alpha}=\mathbf{0 , 0 5} \boldsymbol{p}<\boldsymbol{\alpha}$
\end{tabular}

The highest number of childbirth in the case group was normal delivery $(46,7 \%)$, while in the control group was $38 \%(58,5 \%)$. Chi Square test results show $\mathrm{p}=0.024$ then $\mathrm{p}<\alpha$, means there is a significant relationship between the type of labor with postpartum urinary retention incident in RSUD dr. $\mathrm{H}$. Soemarno Sosroatmodjo Kuala Kapuas in 2015-2016 


\section{DISCUSSION}

1. Episiotomy

Episiotomy is often performed in hospitals dr. H. Soemarno Sosroatmodjo Kuala Kapuas due to rigid perineal reason $\&$ accelerate labor process. In addition, an episiotomy is performed for labor that needs action, whereas the episiotomy is not maternal cesarean section and the mother with elastic perineum ${ }^{14}$. This is done to shorten the time in pushing the baby out so as to prevent the suppression of the baby's old head in the bladder. Episiotomy is performed on the indications of fetal distress and vaginal delivery with complications ${ }^{2}$.

Episiotomy has a significant relationship with maternal age, primipara, fetal distress \& second stage of the second

\section{Perineal rupture}

The number of postpartum women who have rupture of the perineum caused by almost all labor vaginally will certainly cause rupture, but the rupture that occurs differently is due to the episiotomy that also occurs spontaneously. This rupture can occur due to factors during labor such as how to mistake the wrong mother, big baby, elastic muscle of the perineum and from the factor of the wrong helper in making arrest on the perineum, whereas that does not experience rupture perineum because at the time of delivery by way seksio sesarea $^{10}$.
Rupture of the perineum may be affected by several factors, namely maternal factors such as precipitate partus, incorrect way of casting, parity, perineal scarring, labor with action ${ }^{9}$.

3. Type of Labor

The most common childbirth is normal delivery because medical personnel at RSUD dr. $\mathrm{H}$ Soermarno Sosroatmodjo Kuala Kapuas always strives and strongly encourages the mother to give birth normally which is the most ideal childbirth. Normal delivery occurs in an unpublished, induced, single (fetal) pregnancy with anterior rear and head presentation, excluding complications, normal birth placenta, normal infant, while for cesarean section and vacuum extraction is avoided as much as possible because it has more risks for both mother and baby, except for certain indication.

Older stage II mothers, having compensated cardiac disease, fibrotic lung disease and tired fatigue require immediate labor by using vacuum extraction, while mothers with a history of SC, placenta previa, placental abruption and abnormal fetal location require delivery with cesarean section ${ }^{10}$.

Normal birth is more ideal for minimizing the complications, the artificial birth (cesarean section \& vacuum extraction) is done on a particular indication $^{8}$. 
4. Relationship Episiotomy with Retensio Post Partum

Particular Event Episiotomy can affect the occurrence of urinary retention. Postpartum mother who performed episiotomy in RSUD dr. H. Soemarno Sosroatmodjo Kuala Kapuas after childbirth mostly holds the BAK out of fear and burning if the mother is BAK. In addition, the fear of walking to the toilet made Mother hold her urination as well.

Urinary retention occurs as a result of episiotomy incision pain causing urinary inhibition effects and resulting in a burning sensation that decreases or alters urinary reflexes. Episiotomy is one of the risk factors causing urinary retention due to decreased reflexes in the urethra with statistical test results $\mathrm{p}=0.022^{3,18}$.

5. Relationship of the Perineum Rupture with Retensio Postpartum Urine Occurrence

Similarly, episiotomy, perineal rupture performed can affect the occurrence of urinary retention. Postpartum mother who has rupture perineum in dr. H. Soemarno Sosroatmodjo Kuala Kapuas after childbirth mostly hold BAK because of the pain around the perineum area. In addition, the perineal rupture that occurs can be up to the bladder detrusor muscle area thus decreasing urinary reflexes after delivery.

Urinary retention occurs as a result of rupture of the perineum causing urinary inhibition effects and causing a seizure bladder. This study is also in line with a study by Cavkaytar which states that perineal rupture is one of the risk factors that cause urinary retention caused by decreased reflexes in the urethra with statistical test results $p=0.001$. However, it is not in line with Pangadongan research which states that there is no correlation of perineal wound with postapital urinary retention incident with statistical results $p$ $=0,236^{3,18}$.

6. Relationship Type of Labor with Retensio Post Urum Particle Event The type of labor chosen by the puerperal mother may also affect the occurrence of urinary retention. Postpartum mother who chooses delivery normally in RSUD $\mathrm{dr}$. $\mathrm{H}$. Soemarno Sosroatmodjo Kuala Kapuas will result in urinary retention due to long fetal head arrest in the bladder detrusor muscle. Postpartum women who choose vacuum extraction may also result in urinary retention as well as normal labor because the second stage of the second makes the fetal head suppress the bladder so as to decrease the desire for the BAK. In addition, cesarean section delivery may also cause urinary retention due to the use of epidural anesthesia which may decrease bladder sensitivity to intravesical fluid pressure.

Postoperative and postpartum patients constitute the most part causing acute urinary retention. Urinary retention occurs 
as a result of bladder trauma and secondary edema due to surgery or obstetrics, epidural anesthesia, narcotic drugs, stretching or trauma of the pelvic nerves. There is a long-term type of labor relationship with the incidence of postsaline urinary retention. The most common type of labor in Zebrine studies is the type of perabdominal labor ${ }^{18,20}$.

\section{CONCLUSION}

From the results that have been done it can be concluded that there is a relationship between episiotomy, perineum rupture and type of delivery with post partum urinary retention incident in RSUD dr. H. Soemarno Sastroatmodjo Kuala Kapuas in 2015 - 2016.

\section{REFERENCE}

1. Andi. Retensio Urin Post Partum, Dalam : Jurnal Kedokteran Indonesia, Vol 20, Februari 2008

2. Benson, Ralp C \& Martin L. Pernol.. Buku Saku Obstetri dan Ginekologi Edisi 9. Jakarta: EGC; 2009

3. Cavkaytar, Sabri. Postpartum urinary retention after vaginal delivery: assessment of risk factors in acasecontol study. J Turk Ger Gynecol Assoc [Internet]. 2014. [di akses 23 November 2016]; 15: 140-143. www.pubmed.com
4. Dinas Kesehatan Provinsi Kalteng. Profil Kesehatan Kabupaten Kapuas Tahun 2014. Banjarmasin: Dinkes Provinsi Kalteng; 2014a.

5. Profil

Kesehatan Kalimantan Tengah Tahun 2014. Banjarmasin: Dinkes Provinsi Kalteng; 2014b.

6. Kementrian Kesehatan Republik Indonesia, 2015. Profil Kesehatan Indonesia Tahun 2015. Jakarta: Kementrian Kesehatan Republik Indonesia

7. Mulder, Femke E. M. Delivery-related risk factors for covert postpartum urinary retention after vaginal delivery. J. Urogynecol Int [Internet]. 2016. [di akses 26 November 2016]; 27:55-60. www.pubmed.com

8. Novidawasti, Anita. Hubungan Antara Jenis Persalinan Dengan Tingkat Asfiksia Neonatorum di RSUD Panembahan Senopati Bantul tahun 2013 [Skripsi]. Yogyakarta. Program Studi Bidan Pendidik Jenjang DIV Sekolah Tinggi Ilmu Kesehatan Aisyiyah Yogyakarta; 2014

9. Nugroho, Taufan. 2012. Patologi Kebidanan. Yogyakarta: Nuha Medika 10. Prawirohardjo, Sarwono. Buku Acuan Nasional Pelayanan Kesehatan Maternal dan Neonatal. Jakarta: Bina Pustaka; 2009 
11. Pribakti B. Tinjauan Kasus Retensi Urin

Post Partum di RS Ulin Banjarmasin 2002-2003. Dexa Medica, 2006

12. Purwitasari, E. dkk. Penyebab Terjadinya

Ruptur Perineum pada Persalinan

Normal di RSUD Muntilan Kabupaten

Magelang. Jurnal Ners dan Kebidanan

Indonesia. 2015. Vol. 3, No.2 Tahun 2015: 77-81

13. Rahman, Aulia. Retensi Urin Post

Partum. Riau: Fakultas Kedokteran

Universitas Riau Pekanbaru; 2009

14. Rasouli M, Keramat A, Khosravi A.

Prevalence and Factors Associated

With Episiotomy in Shahroud City,

Northeast of Iran. International

Journal of Women's Health and

Reproduction Sciences [Internet]. 2016.

[di akses 20 Mei 2017]; Vol. 4 No.

3:125-129. www.pubmed.com

15. Saultz JW, Toffler WL, Shackles JY.

Postpartum Urinary Retention. J. Am

Board Fam Pract [Internet]. 1991. [di

akses 16 November 2016]; 4:341-344..

www.pubmed.com

16. Utami, Hilda Ekasari, dkk. Waktu

Pertama Buang Air Kecil (BAK) pada

Ibu Post Partum yang dilakukan

Bladder Training. Jurnal Ilmu

Kesehatan Vol VI No. 1, Maret 2014

17. Walyani, Elisabeth Siwi. Asuhan

Kebidanan Pada Masa Nifas.

Yogyakarta: Pustaka Baru Press; 2015
18. Wiknjosastro, Hanifa. Ilmu Kebidanan Edisi ketiga. Jakarta: Yayasan Bina Pustaka Sarwono Prawirohardjo; 2007

19. Yustini, E., dkk. Efektivitas Bladder Training Terhadap BAK Spontan Post Patum. Majalah Obsterti Ginekologi Indonesia. Vol. 32 : 4, Oktober, 2008

20. Zebrina, Trisianita. Hubungan Jenis Pertolongan Persalinan Kala II Lama Dengan Kejadian Retensio Urin Pascasalin di Ruang Nifas RSUD Dr. H. Soemarno Sostroatmodjo Kuala Kapuas tahun 2013-2014 [Skripsi]. Banjarmasin. Program Studi DIV Bidan Pendidik Sekolah Tinggi Ilmu Kesehatan Sari Mulia Banjarmasin; 2014 